\title{
Effect of geomagnetic field on whitefly Bemisia tabaci (Gennadius) flight to the cardinal and halfway directions and their attraction to different colors in Jeddah of Saudi Arabia
}

\author{
Samia M. M. Saleh , Layla A. H. Al-Shareef and Raja A.A. Al-Zahrany \\ Faculty of Science for Girls, King Abdul Aziz University, Jeddah, Saudi Arabia \\ Corresponding author's . Tel.: + $0564469922,+20124019238 \mathrm{E}-m a i l$ address : \\ Layladr@hotmail.com
}

\begin{abstract}
Whitefly Bemisia tabaci (Gennadius) is well-known as serious pest on economic plants all over the world. In this study we examine the effect of geomagnetic field on the whitefly $B$. tabaci flight to the cardinal (north, south, west and east) and halfway (north-east, south-east, north-west and southwest) directions in Jeddah of Saudi Arabia. Also, we studied the effect of geomagnetic field on the attraction of $B$. tabaci adults to five colors (yellow, orange, green, blue and violet). We found that , $B$. tabaci females oriented to the cardinal and halfway directions significantly more than males. Also, there were no significant differences in the total numbers of $B$. tabaci adults attracted to the four main directions. South east was significantly the most halfway direction which $B$. tabaci attracted to. Statistically, yellow color was significantly the most attractive color, while blue and violet were the least colors preferred by $B$. tabaci
\end{abstract}

Keywords Whitefly, Bemisia tabaci, flight, attractive, directions, colors.

\section{INTRODUCTION}

Whitefly Bemisia tabaci (Gennadius) is a widely distributed pest throughout the crops of the tropics, subtropics and temperate regions (Wolfe et al., 1998 ; Oliveira et al., 2001), and have been considered as a dangerous agricultural pest for more than four decades (Byrne et al., 1990). Whitefly can damage the plant directly by sucking the plant sap which contains many important nutrients, and this leads to reduce plants vitality, productivity and causes plant damage (Alegbejo and Banwo, 2005.) The whitefly in all its stages can also damage the plant indirectly by secreting honeydew which leads to growth of sooty mold fungi, and this can affect the plants physiological processes (Bi et al., 2001), in addition, it transmits the plant virus (Morales and Jones, 2004). It has been found that the earth magnetic field is one of the most important factors that effects on the whitefly $B$. tabaci flight direction, and it was proved it orients toward the east then south, north, and finally to the west (Mohamed, 2007). Also it was found that color is an important factor for the whiteflies in selecting the host plant, where whitefly attracts to different wavelengths ranging between long that attract it to the host plant, and a short wave associated with migratory behavior (Osman, 1996). It was reported that whitefly $B$. tabaci was positive to the movement of light, as it was attracted to two ranges of wavelengths that is bluish-violet and yellow, female whiteflies were always attracted to the yellow color ( Pereira and Laurentin, 2001 ; Chu et al., 2007). But, Vaishampayan et al. (1975) have proved that Trialeurodes vaporariorum made a response to the yellow-green color in large numbers with a wavelength ranging from 520 to $610 \mathrm{~nm}$. Affeldt et al. (1983) reported that the highest number of greenhouse whitefly $T$. vaporariorum was on traps reflecting radiation with wavelength between $500-600 \mathrm{~nm}$. Chu et al. (2000) also had proved that out of the nine examined colors that used to record the attraction of the whitefly Bemisia argentifolli Bellows and Perring with a wavelength range between 490 to $600 \mathrm{~nm}$, the most attracted colors were (yellow-green, then yellow, and then spring green).

Therefore, the aim of this research is to study the effect of geomagnetic field on the whitefly Bemisia tabaci (Gennadius) flight to the four cardinal directions (north, south, east and west) as well as the half way directions (north-east, south-east, north- 
west and south-west), in addition to study the effect of geomagnetic field on the attraction of the adult whitefly to five different colors (yellow, orange, green , blue and violet).

\section{MATERIALS AND METHODS}

Rearing of the whitefly $B$. tabaci (Gennadius) in laboratory: The eggplant was selected as a host plant for the whitefly $B$. tabaci. Seeds were planted in a plastic basin $\left(33 \times 18 \times 17 \mathrm{~cm}^{3}\right)$, then plants in age of 25-30 days were planted in plastic pots $(10 \mathrm{~cm}$ in diameter), and were used about a week after transplanting. Whiteflies $B$. tabaci were reared in a wooden cages, $\left(2 \times 1.5 \times 1 \mathrm{~m}^{3}\right)$ each side was covered by muslin cloth while the roof and the front were from glass, and equipped with a source of lighting. A number of males and females whitefly $B$. tabaci were collected from the infested plants using an aspirator and put into rearing cages on the eggplant seedlings that were cultivated. Insects were left to complete their life cycle at a temperature $25-32^{\circ} \mathrm{C}$ and a relative humidity $65-70 \%$. The insect have been rearing for several generations to be used in laboratory experiments.

Attraction of the adult whitefly $B$. tabaci (Gennadius) to the cardinal and halfway directions: In this experiment we used a wooden cage $\left(1 \times 1 \times 1 \mathrm{~m}^{3}\right)$. The cage was designed to study the effect of the earth magnetic field on the flight direction preference of whitefly $B$. tabaci (Gennadius), the inside of the cage was painted with a black color to ensure total darkness. We made five circular holes $(6 \mathrm{~cm}$ in diameter) on each the four side of the cage to hold five plastic jars $(3.25 \mathrm{~cm}$ in diameter and a length of $18 \mathrm{~cm}$ ), and it's opening to the inside of the cage. The cage was placed, where each direction of the box is facing the four cardinal compass directions, along with another test in which each side of the box was placed to the four half way directions (north-east, south-east, south-west, and north-west) (Figure 1). During this study, a transparent clean jars were used. A compass was used to determine the cardinal and halfway directions.

Attraction of the adult whitefly $B$. tabaci (Gennadius) for colors: In this experiment we used the same cage that used in the previous experiment, and we have colored the jars in each of the four sides of the cage with five different colors and it's wavelength have been measured by using a spectrometer, and the colors were violet $(431 \mathrm{~nm})$, blue $(468 \mathrm{~nm})$, green $(505 \mathrm{~nm})$, yellow $(580 \mathrm{~nm})$ and orange $(595 \mathrm{~nm})$ taking into consideration to paint the jars from the outside (Fig. 2).

Before starting the experiment of the whitefly's attraction for the cardinal and half way directions and colors, whiteflies were collected from the eggplant plants in the rearing cages, by using an aspirator, and then were put in the freezer from 2 to 3 minutes at a temperature $-4^{\circ} \mathrm{C}$ to make it numbed, and placed on a paper inside the cage, and left to 30 to 45 minutes until the insect restored it's activity and began to move and fly towards the jars in each direction. At the end of the experiment we collected the jars after been closed and placed in a freezer overnight to kill the insects. Males and females were counted in each jar, to find out the directions and colors that have attracted the insect the most. This experiment was repeated four times

Measurement of the wavelength of the colors: To estimate the wavelength of each color in the visible region of the spectrum for electromagnetic radiation, we used spectrometer apparatus and diffraction grating, which contains a large number of slits up to 600 slit, and it has been measured the value of the angle $\theta$, which gives the highest intensity of brightness for color, with knowing that, slit width d, the angle $\theta$ and the order of the line to the specified color n (Bush, 1996), wavelength of color was determined from the relation:

$$
\mathrm{n} \lambda=\mathrm{d} \sin
$$

Statistical analysis: The data were subjected to statistical analysis according to Watson \& Croft (1993).

\section{RESULTS}

Effect of geomagnetic field on the flight direction of the adult whitefly $B$. tabaci, toward the cardinal and halfway directions: Results from statistical analysis had proved that there was a highly significant differences between the four cardinal directions which the whitefly B.tabaci was attracted to and between the sex of B.tabaci which attracted to these directions. Table (I) demonstrates that the direction of the east (3.09) was more significant in the mean number of $B$. tabaci, and the mean number of females that attracted to this direction (3.60) was more significant than males (2.59), and east of Jeddah (3.09) did not differ significantly from the north and south of Jeddah in the mean number of $B$. tabaci (2.03 and 2.16, respectively). The mean number of females attracted to each of the north and south directions (2.56 and 2.36) did not differ 
significantly from the mean number of male ( 1.50 and 1.96, respectively). The mean number of $B$. tabaci flying toward the west (1.73) was least significant from the other directions, but did not differ significantly from both north and south. The mean number of females in the west direction (2.09) did not differ significantly from the mean number of males (1.37).

When the test cage was directed to the four halfway directions between the cardinal directions, statistical analysis results showed that there were a highly significant differences in the mean number of the attracted $B$. tabaci, due to the different factors of the directions and the sex of the attracted $B$. tabaci. Table (II) demonstrates that there were significant differences between the mean number of attracted $B$. tabaci toward each halfway direction, and these numbers were in descending order, the south-east (32.4), north-east (27.05), north-west (21.65) and south-west (18.15). The mean number of females attracted to each half way direction (the north-east; south-east; north-west and south-west) were more significantly than males $(17.75 \& 9.3 ; 20.65 \& 11.75$ ; $14.0 \& 7.65$ and $12.05 \& 6.1)$. Overall, the mean number of females which attracted to all directions (16.11) was more significant than males (8.7), meaning that the most attractive half way direction for B.tabaci was the south east of Jeddah.

Effect of geomagnetic field on whitefly's flight direction toward the cardinal directions and the different colors: Statistical analysis results had proved that there was a highly significant differences in the mean numbers of the attracted B.tabaci, due to the difference between the cardinal directions, the colors used to attract B.tabaci and the sex of the attracted B.tabaci. Table (III) demonstrates that there were significant differences between the numbers of B.tabaci attracted to the four cardinal directions, and they were in descending order, females of the east (12.65), females of the south (11.05), females of the north (9.45), males of the east (6.55) and south (5.20), which they did not differ significantly from each other, then each of the females of the west (4.90) and males of the north (4.05), but the males which oriented toward the west were the least significant (2.10). Meaning that the females often were significantly larger than males in the attraction to the different directions.

When comparing the mean total number of the attracted B.tabaci to the different colors, we found that the yellow color (13.72) was more significant from orange (9.06), and did not differ significantly from green (5.75), which in turn did not differ significantly from the blue (4.06) and violet (2.38) colors.

Effect of geomagnetic field on whitefly's flight direction toward the halfway directions and the different colors : When the test cage with the colored jars of the five colors, were directed to the four halfway directions in-between the four main directions, it showed that there were strong effects on the flight direction of whitefly $B$. tabaci to the different half way directions resulted from the wavelength of the used colors. The statistical analysis results indicated that there were significant differences due to different factors, which were the half way directions, the colors used to attract B.tabaci and the sex of B.tabaci that attracted to these colors. Table (IV) shows significant difference in the mean number of B.tabaci attracted to the half way directions in descending order for females of the south-east (16.90), females of the north-east (14.05), females of the north-west (11.90), females of the south-west (10.10), males of the south-east (9.55), males of the north-east (7.85), males of the north-west (6.40) and males of the south-west (5.15)

When comparing the different colors in the extent of attracting whitefly $B$. tabaci, we found that the mean number of B.tabaci attracted to the yellow color (15.72) was the most significant, followed by orange (13.06), which in turn was more significant than green (10.56), and more significant from the blue (7.56), and finally the least significant color was violet (4.28).

\section{DISCUSSION}

Over the last seventeen years, a number of scientists have studied the effect of magnetic field on the direction of insect flight. Philips and Sayeed (1993) have studied the effect of magnetic fields on Drosophila melanogaster, and Camlitepe and Stradling (1995) have recorded the response of the wood ant Formica rufa toward the magnetic field. Strickman et al. (2000) also have studied the mosquitoes' response to the magnetic field. Previous studies have showed that many insects have a magnetic sense use it when moving from one place to another. The results of our present study show that there are no significant differences between the four cardinal directions that whitefly $B$. tabaci was attracted to, moreover, the attraction of the females toward these directions were significantly higher than males. For the halfway directions, the south-east was significantly the most attractive direction for the whitefly $B$. tabaci and by looking at this direction we 
find that it leads to the Kaaba where Muslims turn their faces when they do prayers. The insect, like other organisms, recognizes its creator through its innate feeling. It also glorifies Allah and praises Him innately. The results of our study differ from Mohamed's result (2007) who has proved that $B$. tabaci was orientated to the east, then south, then north, and finally to the west.

The insect's phototropism and color vision, consider the most important factors that help the insect in identifying it's food supply (Giurfa et al., 1995 ; Horvath et al., 2002). The insects often respond to the different band wavelengths with a different behavior (Johnson and Midgley, 2001 ; Weiss \& Papa, 2003) and they use the different colors to distinguish between the host and the surrounding environment (Begum et al., 2004). While Blackmer et al. (1994) reported that the attraction of $B$. tabaci to light depends on the color vision which attract it to the host plant $(550 \mathrm{~nm})$. Many studies have been conducted on the colors which many types of whiteflies are attracted to. Mound (1962) reported that $B$. tabaci was responded to two wavelengths, the blue/ultra-violet and the yellow. Also he found that the short-wavelength (Blue-UV) plays a role in the migratory behavior but the attraction to the long wavelength help it to find the host plant places easily. That means the insects can be effected by the color of the surface and respond to it. The present study proved that the yellow color in a wavelength of 580 $\mathrm{nm}$ was the most attractive color for whitefly $B$. tabaci, and that due to the importance of laying the eggs on the young leaves which are more yellowish than the adult leaves. The violet color $(431 \mathrm{~nm})$ was the least attractive. Our results were very similar to the results of Weeb et al. (1985) where they proved that the attractiveness of the yellow color is because it is a radiant color with the highest reflection, while the light reflection for the violet color is low. Our current results also corroborate with Vaishampayan et al. (1975) experiment in the extent of greenhouse whitefly (Trialeurodes vaporariorum) attraction to the reflected light from several painted oily surfaces. Where he proved that insects were attracted in a large numbers to the yellow-green color with a wavelength between 520 to $610 \mathrm{~nm}$, but it's response to ultra violet light with a wavelength less than 400 $\mathrm{nm}$ or infrared at a wavelength between 610 to 700 $\mathrm{nm}$ was normal. Also the results of our study agree with Affeldt et al. (1983) when they emphasized that the greenhouse white fly $T$. vaporariorum recorded the highest response to the yellow-green color at the wavelength of $500-600 \mathrm{~nm}$, but the blue color (400-
490) inhibited the response. Balan (1967) in India also reported that the growth of whitefly $B$. tabaci was faster when it was exposed to the yellow-green color, while it was slower in light blue. While EL-Helaly et al. (1981a) in Egypt has emphasized that the females and males of whitefly B. tabaci prefers yellow ( 700$520 \mathrm{~nm}$ ) in comparing with green, white and blue colors.

Our present study showed that the orange color comes after the yellow color which is the most attractive color for whitefly $B$. tabaci, and the orange followed by green, then blue and finally violet for both males and females of whitefly $B$. tabaci. The females were always significantly greater than males in being attracted to these colors. But, EL-Helaly et al. (1981b) had proved a contrast result as he emphasized that only the females response to the yellow color, then green, white, blue, and finally the red color, while the males don't prefer any color from the other. Gaum and Giliomee (1994) in South Africa had emphasized that the greenhouse whitefly ( $T$. vaporariorum) respond to the yellow color with a wavelength of $600 \mathrm{~nm}$. Mutwiwa and Tantau (2005) also proved that the whitefly $T$. vaporariorum attracted to lamps of the yellow color. In the United States, India and China Chu et al. (2000) have said that when using nine different colors, the yellow was the most attractive for the whitefly then green, and then the orange, with wavelength range between 490 to $600 \mathrm{~nm}$, and these colors consider the primary colors in attracting insects, as it's wavelength similar to the reflected light waves from the underside of the lush green leaves and this was confirmed by our current results. Simmon (2003) emphasized that, when blue, yellow and white traps were used to attract whitefly $B$. tabaci, the yellow traps were more attractive. Chu et al. $(2003,2004)$ also confirmed our results, where they used two types of traps, which are yellow sticky card and plastic cup to catch the whitefly $T$. vaporariorum and Bemisia argentifolli and aphid Aphis gossypii they found that the yellow traps in greenhouse which equipped with a yellow-green light, have been most effective in attracting the largest number of insects and limits it's spreading, than those traps that were not provided with lighting. As well as in Egypt, Mohamed (2007) have studied the colors and directions that insect $B$. tabaci attracted to, where he proved that the yellow color was more significant from the bluish green, and than the orange, indigo, and the green, this corroborate with our results, in that the yellow color is more significant from other colors. 
.Fig. 1. The cage that used for whitefly B. tabaci_attraction toward the cardinal and half way directions.

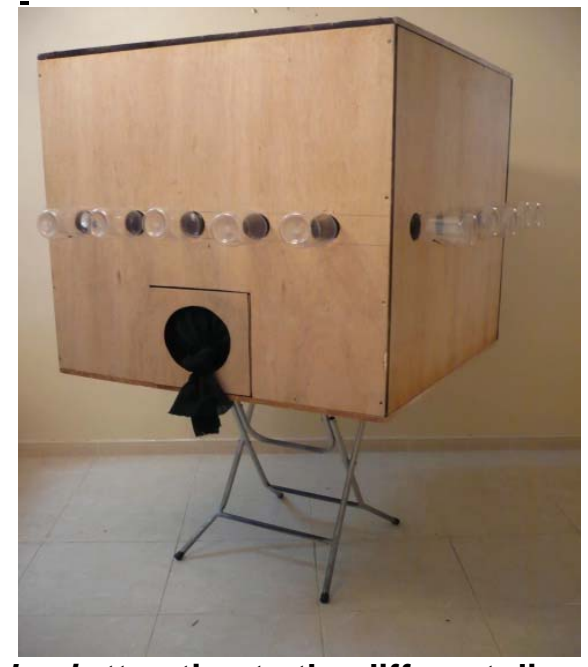

Fig. 2 The cage that used for whitefly B. tabaci attraction to the different directions and colors.

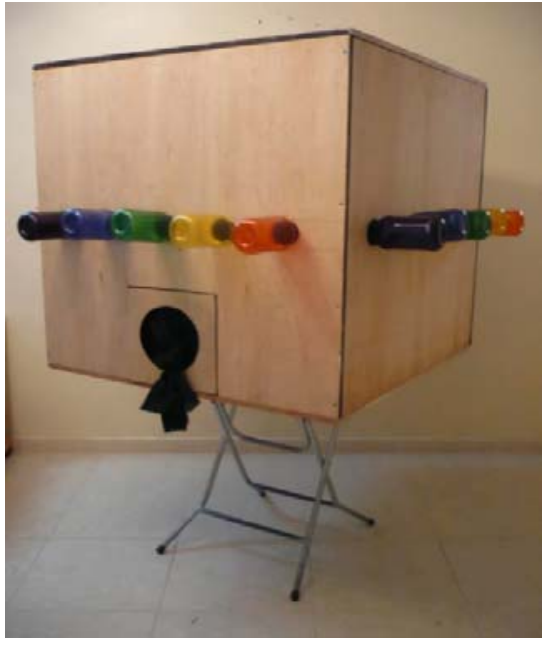

Table 1. Mean number of male and female whitefly $B$. tabaci which attracted toward the main directions.

\begin{tabular}{|c|c|c|c|c|c|}
\hline \multirow{2}{*}{ Sex } & \multicolumn{4}{|c|}{ Mean directions } & \multirow{2}{*}{ The mean } \\
\cline { 2 - 5 } Male & East & West & North & South & \multirow{2}{*}{$1.85 \mathrm{~B}$} \\
& $2.59 \mathrm{Ba}$ & $1.37 \mathrm{Aa}$ & $1.50 \mathrm{~A} \mathrm{a}$ & $1.96 \mathrm{~A} \mathrm{a}$ & \\
\hline Female & $3.60 \mathrm{Aa}$ & $2.09 \mathrm{Ab}$ & $2.56 \mathrm{~A} \mathrm{ab}$ & $2.36 \mathrm{~A} \mathrm{ab}$ & $2.65 \mathrm{~A}$ \\
\hline The mean & $3.09 \mathrm{a}$ & $1.73 \mathrm{~b}$ & $2.03 \mathrm{ab}$ & $2.16 \mathrm{ab}$ & 2.25 \\
\hline
\end{tabular}

Different letters mean that there are significant differences between the mean value

Capital letters are present in the vertical comparison

Small letters are present in the horizontal comparison 
Table 2. Mean number of male and female whitefly B. tabaci which attracted toward the half way directions.

\begin{tabular}{|c|c|c|c|}
\hline \multirow{2}{*}{$\begin{array}{c}\text { Half way } \\
\text { directions }\end{array}$} & Male & Fex & \multirow{2}{*}{ Mean } \\
\cline { 2 - 3 } & $9.3 \mathrm{~B} \mathrm{~b}$ & $17.75 \mathrm{~B} \mathrm{a}$ & $27.05 \mathrm{~B}$ \\
\hline North-east & $11.75 \mathrm{~A} \mathrm{~b}$ & $20.65 \mathrm{~A} \mathrm{a}$ & $32.4 \mathrm{~A}$ \\
\hline South-east & $7.65 \mathrm{BC} \mathrm{b}$ & $14.0 \mathrm{C} \mathrm{a}$ & $21.65 \mathrm{C}$ \\
\hline North-west & $6.1 \mathrm{C} \mathrm{b}$ & $12.05 \mathrm{D} \mathrm{a}$ & $18.15 \mathrm{D}$ \\
\hline South-west & $8.7 \mathrm{~b}$ & $16.11 \mathrm{a}$ & 12.406 \\
\hline Mean & &
\end{tabular}

Different letters mean that there are significant differences between the mean value.

Capital letters are present in the vertical comparison.

Small letters are present in the horizontal comparison.

Table 3. Mean number of male and female whitefly B. tabaci which attracted toward the colors in cardinal directions

\begin{tabular}{|c|c|c|c|c|c|c|c|}
\hline \multirow[b]{2}{*}{$\begin{array}{c}\text { Mean } \\
\text { directions }\end{array}$} & \multirow[b]{2}{*}{ Sex } & \multicolumn{5}{|c|}{ Colors } & \multirow[b]{2}{*}{ Mean } \\
\hline & & Orange & Yellow & Green & Blue & Violet & \\
\hline \multirow[t]{2}{*}{ East } & Male & $6.25 \mathrm{Bb}$ & $12.5 \mathrm{Ba}$ & $6.5 \mathrm{ABb}$ & $5.0 \mathrm{Ab}$ & $2.5 \mathrm{Ab}$ & $6.55 \mathrm{D}$ \\
\hline & Female & $18.0 \mathrm{Ab}$ & $23.25 \mathrm{Aa}$ & $9.5 \mathrm{Ac}$ & $7.5 \mathrm{Acd}$ & $5.0 \mathrm{Ad}$ & $12.65 \mathrm{~A}$ \\
\hline \multirow[t]{2}{*}{ West } & Male & $2.25 \mathrm{Ba}$ & $4.0 \mathrm{Ca}$ & $2.0 \mathrm{Ca}$ & $1.25 \mathrm{Ba}$ & $1.0 \mathrm{Aa}$ & $2.10 \mathrm{~F}$ \\
\hline & Female & $6.75 \mathrm{Bab}$ & $9.5 \mathrm{Ba}$ & $4.25 \mathrm{BCbc}$ & $2.75 \mathrm{Bbc}$ & $1.25 \mathrm{Ac}$ & $4.90 \mathrm{DE}$ \\
\hline \multirow[t]{2}{*}{ North } & Male & $3.75 \mathrm{Bb}$ & $8.5 \mathrm{Ba}$ & $4.25 \mathrm{BCab}$ & $2.5 \mathrm{Bb}$ & $1.25 \mathrm{Ab}$ & $4.05 \mathrm{E}$ \\
\hline & Female & $14.25 \mathrm{Ab}$ & $19.25 \mathrm{Aa}$ & $6.5 \mathrm{ABc}$ & $4.5 \mathrm{ABC}$ & $2.75 \mathrm{Ac}$ & $9.45 \mathrm{C}$ \\
\hline \multirow[t]{2}{*}{ South } & Male & $4.75 \mathrm{Bb}$ & $10.75 \mathrm{Ba}$ & $\begin{array}{c}5.25 \\
A B C b\end{array}$ & $3.5 \mathrm{ABb}$ & $1.75 \mathrm{Ab}$ & $5.20 \mathrm{D}$ \\
\hline & Female & $16.5 \mathrm{Aa}$ & $22.0 \mathrm{Aa}$ & $7.75 \mathrm{ABb}$ & $5.5 \mathrm{ABb}$ & $3.5 \mathrm{Ab}$ & $11.05 \mathrm{~B}$ \\
\hline \multicolumn{2}{|c|}{ Mean } & 9.06 & $13.72 \mathrm{a}$ & $5.75 \quad b c$ & $4.06 \mathrm{C}$ & $2.38 \mathrm{c}$ & 6.99 \\
\hline
\end{tabular}

Different letters mean that there are significant differences between the mean value.

Capital letters are present in the vertical comparison.

Small letters are present in the horizontal comparison.

Table 4. Mean number of male and female whitefly B. tabaci which attracted toward the colors in the half way directions.

\begin{tabular}{|c|c|c|c|c|c|c|c|}
\hline \multirow{2}{*}{$\begin{array}{c}\text { Mean } \\
\text { directions }\end{array}$} & \multirow[b]{2}{*}{ Sex } & \multicolumn{5}{|c|}{ Colors } & \multirow[b]{2}{*}{ Mean } \\
\hline & & Orange & Yellow & Green & Blue & Violet & \\
\hline \multirow[t]{2}{*}{ North east } & Male & $10.0 \mathrm{Ea}$ & $11.5 \mathrm{Fa}$ & $8.0 \mathrm{~Eb}$ & $6.5 \mathrm{DE} b$ & $\begin{array}{c}3.25 \mathrm{DE} \\
\mathrm{C}\end{array}$ & $7.85 \mathrm{~F}$ \\
\hline & Female & $17.5 \mathrm{Bb}$ & $21.5 \mathrm{Ba}$ & $15.0 \mathrm{Bc}$ & $9.75 \mathrm{Bd}$ & $6.5 \mathrm{AB} \mathrm{e}$ & $14.05 \mathrm{~B}$ \\
\hline \multirow[t]{2}{*}{ South east } & Male & $12.5 \mathrm{Da}$ & 13.75 Ea & $9.25 \mathrm{Db}$ & $8.0 \mathrm{Cb}$ & $\begin{array}{c}4.25 \text { CD } \\
c\end{array}$ & $9.55 \mathrm{E}$ \\
\hline & Female & $22.75 \mathrm{Ab}$ & $25.0 \mathrm{Aa}$ & $17.0 \mathrm{Ac}$ & $12.25 \mathrm{Ad}$ & $7.5 \mathrm{Ae}$ & $16.90 \mathrm{~A}$ \\
\hline \multirow[t]{2}{*}{ North west } & Male & $8.5 \mathrm{Ea}$ & $9.75 \mathrm{Ga}$ & $6.5 \mathrm{Fb}$ & 5.0 EF b & $2.25 \mathrm{EF} c$ & $6.40 \mathrm{G}$ \\
\hline & Female & $14.25 \mathrm{Cb}$ & $19.25 \mathrm{Ca}$ & $12.5 \mathrm{Cc}$ & $8.25 \mathrm{BCd}$ & $5.25 \mathrm{BCe}$ & $11.90 \mathrm{C}$ \\
\hline \multirow[t]{2}{*}{ South west } & Male & $6.75 \mathrm{Fb}$ & $8.75 \mathrm{Ga}$ & $5.25 \mathrm{Fb}$ & $3.75 \mathrm{Fc}$ & $1.25 \mathrm{Fd}$ & $5.15 \mathrm{H}$ \\
\hline & Female & $12.25 \mathrm{Db}$ & 16.25 Da & $11.0 \mathrm{Cc}$ & $7.0 \mathrm{CD} \mathrm{d}$ & $4.0 \mathrm{CD} \mathrm{e}$ & $10.10 \mathrm{D}$ \\
\hline \multicolumn{2}{|c|}{ Mean } & $13.06 \mathrm{~b}$ & $15.72 \mathrm{a}$ & $10.56 \mathrm{c}$ & $7.56 \mathrm{~d}$ & $4.28 \mathrm{e}$ & 10.2375 \\
\hline
\end{tabular}

Different letters mean that there are significant differences between the mean value.

Capital letters are present in the vertical comparison.

Small letters are present in the horizontal comparison 


\section{CONCLUSION}

It is concluded that, $B$. tabaci females oriented to the cardinal and halfway directions more than males. South east was the most halfway direction which Bemisia tabaci attracted to, and yellow color was the most attractive color, while blue and violet were the least colors which preferred by $B$. tabaci.

\section{ACKNOWLEDGMENTS}

We would like to acknowledge Prof. Ali Al-Harthi from the faculty of Meteorology, Environment and Arid Land Agriculture (King Abdul Aziz university) for his help

\section{REFERENCES}

Affeldt, H. A. , Thimuan, R. W. , Smith, F. F. and Webb, R. E. (1983): Response of the greenhouse whitefly (Homoptera: Aleyrodidae) and the vegetable leafminer (Diptera : Agromyzidae) to photospectra , J. Econ. Entomol. 76: 1405-1409.

Alegbejo, M. D. and Banwo, O. O. (2005): Host plants of Bemisia tabaci (Genn.) in northern Nigeria , Journal of Plant Protection Research , 45(2).

Balan, J. S. (1967): Effect of different coloured lights on the development of Bemisia tabaci Genn. Plant Protection Bulletin, Science in Practice , 19(1):30-33.

Begum, M., Wratten,S. D. and Nicol, H. I.(2004): Flower color affects tri- trophic-level biocontrol interactions, Biological Control, $30: 584-590$

Bi, J. L. , Toscano, N. C. and Ballmer, G. R. (2001): Seasonal Population dynamics of the Greenhouse Whitefly Trialeurodes vaporariorum on Oxnard area, Department of Entomology, University of California, Riverside, CA 92521.

Blackmer, J. L. , Byrne, D. N. and Tu, Z. (1994): Behavioral , morphological and physiological traits associated with migratory Bemisia tabaci (Homoptera:Aleyrodidae) , Journal of Insect Behavvior , 251-267.

Bush, G.F. (1996): Principles of physics. Magrohil. 325 pp.

Byrne, D. N. , Bellows, T. S. Jr. and Parrella, M. P. (1990): whiteflies in agricultural systems , pp. 227-262 in D Gerling [ed.] whiteflies their bionomics, pest status and management. U.K.

Camlitepe, Y. and Stradling, D.J. (1995): Wood Ants Orient to Magnetic Fields, Proceedings of the Royal Society, 261(1360):37-41.

Chu,C. C. Simmons, A. M. Chen, T. Y. Alexander, P. J. and Henneberry, T. J.(2004): Lime green light-emitting diode equipped yellow sticky card traps for monitoring whiteflies, aphids and fungus gnats in greenhouse , Entomolgia Sinica. 11(2): 125-133.

Chu, C. C. , Chen, T. , Simmons, A. M. , Jackson, C. G. , Alexander, P. J. And Henneberry, T. J. (2003): Development of light- emitting diode(Led) traps for whiteflies and other insects, Proceedings of Integrated Control in Proctected Crops, Mediterranean Climate Congress, pp 27-31.

Chu, C. C. , Barnes, E. , Natwick, E. T., Chen, T. Y. , Ritter, D. and Henneberry, T. J.(2007):Trap catches of the sweet potato whitefly (Homoptera:Aleyrodidae) in the Imperial Valley, California, from 1996 to 2002 , Insect Science, 14(2): 165-170.

Chu, C. C., Pinter, P. J. Jr., Henneberry, T. J. , Umeda, K. , Nawick, E. T. , Wei, Y. A. , Reddy, V. R. and Shrepatis, M. (2000): Use of CC traps with different trap base colors for silverleaf whiteflies (Homoptera : Aleyrodidae), thrips (Thysanoptera : Thripidae), and leafhoppers (Homoptera : Cicadellidae) , J. Econ. Entomol., 93(4) : 1329-37.

El-Helaly, M. S. , Rawash, I. A. and Ibrahim, E. G. (1981a): Phototaxis of the adult whitefly, Bemisia tabaci (Gennadius) to the visible light, I-Effect of the exposure period on the insect's response to different wave lengths of the visible light spectrum using adevised simple technique, Acta phytopathologica Academiae scientiarum Hungaricae, 16(1-2):181-188.

El-Helaly, M. S., Rawash, I. A. and Ibrahim, E. G. (1981b): Phototaxis of the adult whitefly, Bemisia tabaci (Gennadius) to the visible light, II-Effects of both light intensity and sex of the whitefly adults on the insect's response to different wave lengths of light spectrum , Acta phytopathologica Academiae Scientiarum Hungaricae, 16:389-398.

Gaum, W. G. and Giliomee, J. H. (1994): Preference of western flower thrips, Frankliniella occidentalis (Thsanoptera: Thripidae), and greenhouse whitefly , Trialeurodes vaporariorum (Hemiptera :Aleyrodidae), for differently coloured sticky traps, Journal of the Southern African Society for Horticultural Sciences , 4(2):39-41.

Giurfa, M. , Backhaus, W. and Menzel, R. (1995) Color and angular orientation in the discrimination of bilateral symmetric patterns in the honeybee, Naturwissenschaften , 82(4) :198-201.

Hilje, L. and Stansly, Ph. A. (2008): Living ground covers for management of Bemisia tabaci (Gennadius) (Homoptera: Aleyrodidae) and tomato yellow mottle virus (ToYMoV) in Costa Rica, Crop Protection, 27(1) : 10-16.

Horvath , G. Gal , J., Labhart, T. and Wehner, R. (2002): Does reflection polarization by plants influence colour perception in insects polarimetric measurements 
appolied to a polarization sensitive nodel retina of papilis butterflies , J. Exp. Biol. , 25(21): 281-298.

Johnson, S.D, Midgley, J.J. (2001): Pollination by monkey beetles (Scarabaeidae: Hopliini): do colour and dark centres of flowers influence alighting behavior, Environmental Entomology 30: 861-868.

Liu, T. (2007): Life history of Eretmocerus melanoscutus ( Hymenoptera:Aphelinidae) parasitizing nymph of Bemisia tabaci Biotype B (Homoptera:Aleyrodidae), Biological Control, 42(1):77-85.

Mohamed, A. M. S. (2007): Physiological studies on certain economic insects, MSc. Thesis of faculty of Agric. Univ. Alex.

Morales, F. J. and Jones, P. G. (2004): The ecology and epidemiology of whitefly transmitted viruses in Latin America, Virus Research, 100(1) : 57-65.

Mound, L. A. (1962): Studies on the olfaction and colour sensitivity of Bemisia tabaci (Genn.) (Homoptera : Aleyrodidae), Entomolgia experimentallis at applicata., 5:99-104.

Mutwiwa, U. N. and Tantau, H. J. (2005): Suitability of a UV Lamp for Trapping the Greenhouse Whitefly Trialeurodes vaprariorum Westwood (Homoptera: Aleyrodidae), Agricultural Engineering International : the CIGRE journal Vol VII. Manuscript BC 05004 September.

Oliveira, M. R. V. , Henneberry, T. J. and Anderson, P. (2001): History, current status, and collaborative research projects for Bemisia tabaci , Crop Protection, 20(9) : 709-723.

Osman, G. E. H. (1996): Biotyping and biological control of Trialeurodes ricini in Egypt, MSC thesis, Faculty of science, University of Cairo, Egypt.

Pereira, C. and Laurentin, H. (2001): Flight behaviour of the tobacco whitefly (Homoptera:Aleyrodidae) on sesame
(Seasamum indicum L.) in Venezuela, Entomotropica, 16(1): 47-51.

Phillips, J. B. and Sayeed, O. (1993): Wavelength dependent effects of light on magnetic compass orientation in Drosophila melanogaster, Jouranal of Comparative Physiology A : Neuroethology , Sensory, Neural , and Behavioral Physiology, 172(3) : 303-308.

Simmons, A. (2003): Capture of Bemisia tabaci (Homoptera : Aleyrodidae) and Delphastus Catalinae ( Coleoptera : Coccinellidae) on three colors of sticky traps, Journal of Entomologica Science, 38(3) : 481-484.

Strickman, D. , Timberlake, B. , Estrada-franco, J. , Weissman, M. , Fenimore, P. W. and Novak, R. J. (2000): Effects of magnetic fields on mosquitoes, Journal of the American Mosquito control association, 16(2) :131-137.

Vaishampayan, S. M. , Kogan, M. , Waldbauer, G. P. and Woolley, J. T.(1975): Spectral specific response in the visual behavior of the greenhouse whitefly Trialeurodes vaporariorum (Homoptera: Aleyrodidae), Entomologia Experimentalis et Applictata, 18(3): 344356.

Watson, B. and Croft, H., (1993): Statics for management and economics, Allyn and Bacon printed in U. S. A.

Webb, R. E. , Smith, F. F. , Affeldt, H. , Thimijan, R. W. , Dudley, R. F. and Webb, H. F. (1985): Trapping greenhouse whitefly with coloured surfaces: variables affecting efficacy, Crop Protection, 4(3) : 381-393.

Weiss, M. R. and Papa, D. R. (2003): Colour learning in tow behavioural context : abutterfly keep in mind, Annual Behaviour. 65:425-434.

Wolfe, G. R. , Hendrix, D. L. and Salvucci, M. E. (1998): Athermoprotective role for sorbitol in the silverleaf whitefly, Bemisia argentifolii, Journal of Insect Physiology, 44(7-8): 597-603 